DOI:

\title{
USAHA PENINGKATAN KETERAMPILAN GURU SEKOLAH MENENGAH MUHAMMADIYAH DI KAB. GUNUNGKIDUL: PENDAYAGUNAAN LECTORA SEBAGAI MEDIA AJAR
}

\author{
Murein Miksa Mardhia ${ }^{1}$, Dwi Normawati ${ }^{2}$, Ahmad Azhari $^{3}$ \\ Universitas Ahmad Dahlan Yogyakarta ${ }^{1,2,3}$ \\ murein.miksa@tif.uad.ac.id ${ }^{1}$
}

\begin{abstract}
ABSTRAK
Sebuah kegiatan peningkatan keterampilan guru telah diadakan di kalangan Sekolah Menengah Pertama (SMP) wilayah Kabupaten Gunungkidul pada periode semester gasal tahun ajaran 2017/2018. Kegiatan pelatihan TIK ini mengundang tenaga pendidik dari SMP Muhammadiyah di bawah pengelolaan Majelis Pendidikan Dasar dan Menengah (Dikdasmen) PDM Gunungkidul. Tujuan yang ingin dicapai antara lain pengayaan keterampilan tenaga pendidik di bidang TIK sebagai media pendukung kegiatan belajar mengajar di kelas. Dengan peningkatan keterampilan guru-guru sebagai tenaga pendidik melalui TIK, diharapkan dapat mendukung tercapainya pemenuhan kompetensi guru-guru SMP Muhammadiyah di Kabupaten Gunungkidul secara terprogram. Di bagian akhir pelaksanaan, peserta diminta untuk mengumpulkan feedback mengenai kegiatan pelatihan yang telah diikuti. Hasil dan dampaknya, lebih dari $80 \%$ peserta yang hadir menyatakan tingkat kepuasan yang baik terhadap materi, pelaksana, dan kemanfaatan karya yang telah mereka hasilkan. Target usabilitas karya juga telah tercapai sebagai media belajar untuk diaplikasikan di semester genap tahun ajaran 2017/2018.
\end{abstract}

Kata kunci : teknologi, media pembelajaran, Lectora

\begin{abstract}
An activity to improve teacher skills has been held in junior high schools in Gunungkidul Regency during the odd semester holiday period for the 2017/2018 school year. This ICT training activity invited educators from Muhammadiyah secondary schools under the management of the Gunungkidul PDM Primary and Secondary Education Board (Dikdasmen). The goals to be achieved include enriching the skills of educators in the ICT field as a media supporting teaching and learning activities in the classroom. By increasing the skills of the guruguru as educators through ICT, it is expected to be able to support the fulfillment of the competencies of teachers at Muhammadiyah Middle School in Gunungkidul Regency programmed. At the end of the implementation, participants were asked to gather feedback about the training activities that had been followed. More than 80\% of participants present expressed a good level of satisfaction with the material, implementers, and benefits of the work they have produced. The work usability target has also been achieved as a learning media to be applied in the even semester of the 2017/2018 school year.
\end{abstract}

Keywords: technology, course material, multimedia, Lectora 


\section{PENDAHULUAN}

Teknologi informasi diciptakan dengan tujuan untuk membantu kehidupan manusia menyelesaikan masalah yang terjadi, supaya persoalan dapat ditangani dengan lebih cepat dan praktis. Teknologi yang telah menjadi kebutuhan ini yang kemudian juga dimanfaatkan untuk kegiatan manusia salah satunya di bidang pendidikan. Guru-guru di SMP dan SMA telah mulai familiar dengan penggunaan media teknologi untuk pengajaran di kelas, seperti contohnya slide Powerpoint atau dokumen Word. Hanya saja, pemanfaatan media teknologi ini belum digali secara lebih mendalam, sehingga penggunaan satu metode yang terlalu lama membuat kegiatan pembelajaran menjadi monoton. Dari pengalaman inilah kemudian mulai tercipta ide untuk memperluas metode belajar melalui media pembelajaran yang juga berbasis TIK melalui dukungan perangkat lunak Lectora. (Muhson, 2010) menyatakan bahwa media pembelajaran dapat merupakan wahana penyalur pesan dan informasi belajar. Media pembelajaran yang dirancang secara baik akan sangat membantu peserta didik dalam mencerna dan memahami materi pelajaran. Di era globalisasi dan informasi ini, perkembangan media pembelajaran juga semakin maju. Penggunaan Teknologi Informasi (TI) sebagai media pembelajaran sudah merupakan suatu tuntutan.

Kegiatan pelatihan peningkatan keterampilan TIK di kalangan guru sekolah menengah ini merupakan bentuk realisasi dari adanya kerjasama antara Fakultas Teknologi Industri Universitas Ahmad Dahlan (FTI UAD) dengan Majelis Dikdasmen Pimpinan Daerah Muhammadiyah (PDM) Kabupaten Gunungkidul yang disepakati sepanjang tiga tahun ajaran akademik. Salah satu tujuan yang ingin dicapai dari pelatihan ini yaitu peningkatan kualitas guru dan staf pengajar melalui pengayaan keterampilan para tenaga pendidik di bidang TIK sebagai media pendukung kegiatan belajar mengajar di kelas.

Menurut (Siagian, 2008) definisi pelatihan adalah Proses belajar mengajar dengan menggunakan teknik dan metoda tertentu secara konsepsional dapat dikatakan bahwa latihan dimaksudkan untuk meningkatkan keterampilan dan kemampuan kerja seseorang atau sekelompok orang. Kegiatan pelatihan melalui pengabdian masyarakat ini diharapkan dapat memberikan kontribusi dalam penerapan TIK dalam menunjang pendidikan dan pengajaran di sekolah. Dengan peningkatan keterampilan guru-guru sebagai tenaga pendidik melalui TIK, diharapkan dapat mendukung tercapainya pemenuhan kompetensi guru -guru di SMP Muhammadiyah se-Kabupaten Gunungkidul.

Menurut (Depdiknas, 2003) istilah media berasal dari bahasa Latin yang merupakan bentuk jamak dari "medium" yang secara harfiah berarti perantara atau pengantar. Makna umumnya adalah segala sesuatu yang dapat menyalurkan informasi dari 
sumber informasi kepada penerima informasi. Proses belajar mengajar pada dasarnya juga merupakan proses komunikasi, sehingga media yang digunakan dalam pembelajaran disebut media pembelajaran. Media pembelajaran merupakan bagian dari sumber belajar yang merupakan kombinasi antara perangkat lunak (bahan belajar) dan perangkat keras (alat belajar).

Berdasarkan wawancara dengan pihak Majelis Dikdasmen PDM dan beberapa kepala sekolah SMP Muhammadiyah di Gunungkidul, bahwa di wilayah Kabupaten Gunungkidul, sekolah Muhammadiyah jumlahnya cukup banyak dan kemampuan TIK yang dimiliki oleh tenaga pengajar di sana sifatnya beragam.

Salah satu kemampuan yang belum banyak dikuasai yakni belum dapat memanfaatkan TIK untuk membantu mereka menciptakan media untuk mendukung pembelajaran yang berbasis TIK. Hal ini cukup menjadi keterbatasan oleh para guru dalam menciptakan kreatifitas dalam memicu minat siswa saat proses belajar mengajar di kelas. Karena dirasa tidak mampu menguasai sehingga menjadi malas untuk mempelajari dan pada akhirnya akan jauh tertinggal dengan sekolah lain yang sudah mulai memperkaya keterampilan guru dengan banyak mengadakan pelatihan-pelatihan TIK. Untuk itulah tim dari Program Studi Teknik Informatika Universitas Ahmad Dahlan melalui kesediaan dari PDM wilayah Kabupaten Gunungkidul bermaksud untuk mengadakan pelatihan pembuatan media pembelajaran berbasis TIK dengan memanfaatkan perangkat lunak Lectora untuk guru-guru SMP Muhammadiyah se-Kabupaten Gunungkidul, Daerah Istimewa Yogyakarta.

\section{METODE}

Secara garis besar, metode yang dirancang untuk kegiatan ini merupakan gabungan dari tiga komponen metode pelaksanaan. Pada kegiatan pelatihan yang diadakan, terjadi pengenalan teknologi baru melalui perangkat lunak Lectora untuk membuat media pembelajaran dan diselenggarakan sebagai media guru untuk mendidik siswa saat kegiatan belajar mengajar di kelas. Kegiatan yang dilaksanakan melibatkan empat personil mahasiswa dari semester IV dan VI yang bertindak sebagai asisten pemateri dan dapat sekaligus dimanfaatkan sebagai kegiatan Kerja Praktik. Seluruh pengisi materi menerapkan langkah-langkah berikut ini untuk yang selama kegiatan berlangsung :

1. Pemberian modul kepada peserta, sehingga peserta lebih mudah dalam menerima dan memahami materi yang diberikan, sehingga kegiatan ini lebih efektif. 
2. Workshop tutorial, selama kegiatan ini peserta diberikan bimbingan tutorial untuk praktikum (mencoba sendiri) membuat media pembelajaran dengan software Lectora.

3. Pemberian contoh dan kasus permasalahan, peserta mencoba mengerjakan tugas kecil dari pemateri untuk meningkatkkan pemahaman dalam penggunaan fitur-fitur di Lectora untuk media pembelajaran.

4. Feedback dan Evaluasi, pemateri memonitor progres yang dihasilkan peserta secara intensif dan melakukan pendampingan selama workshop. Di akhir kegiatan, pemateri mengumpulkan feedback dari peserta yang hadir.

Tabel 1 mendeskripsikan aktivitas yang dilakukan oleh tim selama workshop berlangsung.

\section{Tabel 1. Rincian Pelaksanaan Program Pelatihan}

\begin{tabular}{|c|c|c|c|}
\hline Kegiatan & Durasi & Lokasi Pelatihan & Penanggungjawab Materi \\
\hline \multicolumn{4}{|l|}{ A. Kegiatan Dalam Kelas } \\
\hline $\begin{array}{l}\text { Pengenalan Lectora dan } \\
\text { Jardiknas }\end{array}$ & 30 menit & $\begin{array}{l}\text { SMP Muhammadiyah } \\
\text { Semin Gunungkidul }\end{array}$ & $\begin{array}{l}\text { Murein Miksa Mardhia, S.T., } \\
\text { M.T. }\end{array}$ \\
\hline $\begin{array}{l}\text { Pembuatan media ajar Lectora : } \\
\text { fitur Design Wizard }\end{array}$ & 150 menit & $\begin{array}{l}\text { SMP Muhammadiyah } \\
\text { Semin Gunungkidul }\end{array}$ & $\begin{array}{l}\text { Murein Miksa Mardhia, S.T., } \\
\text { M.T. }\end{array}$ \\
\hline $\begin{array}{l}\text { Pengaturan elemen multimedia } \\
\text { ke dalam media ajar Lectora }\end{array}$ & 180 menit & $\begin{array}{l}\text { SMP Muhammadiyah } \\
\text { Semin Gunungkidul }\end{array}$ & Dwi Normawati, S.T., M.Eng. \\
\hline $\begin{array}{l}\text { Pembuatan media ajar Lectora: } \\
\text { fitur My Template }\end{array}$ & 60 menit & $\begin{array}{l}\text { SMP Muhammadiyah } \\
\text { Semin Gunungkidul }\end{array}$ & Dwi Normawati, S.T., M.Eng. \\
\hline $\begin{array}{l}\text { Pengaturan objek dalam media } \\
\text { ajar Lectora }\end{array}$ & 60 menit & $\begin{array}{l}\text { SMP Muhammadiyah } \\
\text { Semin Gunungkidul }\end{array}$ & Dwi Normawati, S.T., M.Eng. \\
\hline $\begin{array}{l}\text { Pembuatan Soal Evaluasi dalam } \\
\text { media ajar Lectora }\end{array}$ & 60 menit & $\begin{array}{l}\text { SMP Muhammadiyah } \\
\text { Semin Gunungkidul }\end{array}$ & $\begin{array}{l}\text { Murein Miksa Mardhia, S.T., } \\
\text { M.T. }\end{array}$ \\
\hline $\begin{array}{l}\text { Pembuatan Soal Evaluasi dengan } \\
\text { Lectora : soal pilihan ganda }\end{array}$ & 120 menit & $\begin{array}{l}\text { SMP Muhammadiyah } \\
\text { Semin Gunungkidul }\end{array}$ & $\begin{array}{l}\text { Murein Miksa Mardhia, S.T., } \\
\text { M.T. }\end{array}$ \\
\hline $\begin{array}{l}\text { Pembuatan Soal Evaluasi dengan } \\
\text { Lectora : soal esay }\end{array}$ & 180 menit & $\begin{array}{l}\text { SMP Muhammadiyah } \\
\text { Semin Gunungkidul }\end{array}$ & Ahmad Azhari, S.Kom., M.Eng. \\
\hline $\begin{array}{l}\text { Pembuatan Soal Evaluasi dengan } \\
\text { Lectora : latihan sesuai mapel }\end{array}$ & 120 menit & $\begin{array}{l}\text { SMP Muhammadiyah } \\
\text { Semin Gunungkidul }\end{array}$ & Ahmad Azhari, S.Kom., M.Eng. \\
\hline \multicolumn{4}{|l|}{ B. Kegiatan Luar Kelas } \\
\hline $\begin{array}{l}\text { Latihan menggunakan Lectora } \\
\text { secara mandiri }\end{array}$ & 60 menit x 6 & - & Tim \\
\hline
\end{tabular}

\section{HASIL, PEMBAHASAN, DAN DAMPAK}

Setelah diadakannya pelatihan pembuatan media pembelajaran dengan Lectora ini, peserta dinilai telah dapat:

1. mengikuti kegiatan pelatihan sesuai jadwal yang telah disepakati antara pelaksana dan pemateri. Gambar 1 menunjukkan dokumentasi kegiatan tutorial dan pendampingan oleh pemateri kepada peserta. 


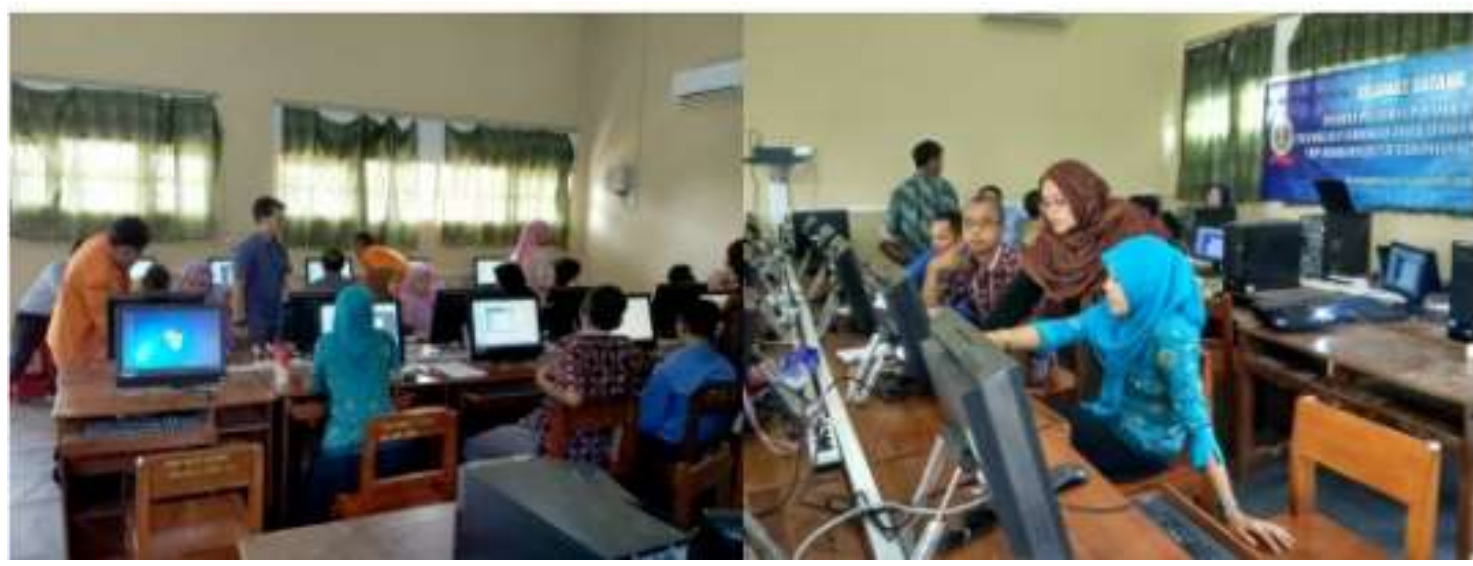

Gambar 1. Tutorial dan Pendampingan

2. menyelesaikan evaluasi dan feedback yang diinstruksikan oleh pemateri. Gambar 2 menampilkan contoh penilaian/evaluasi yang dihasilkan peserta.

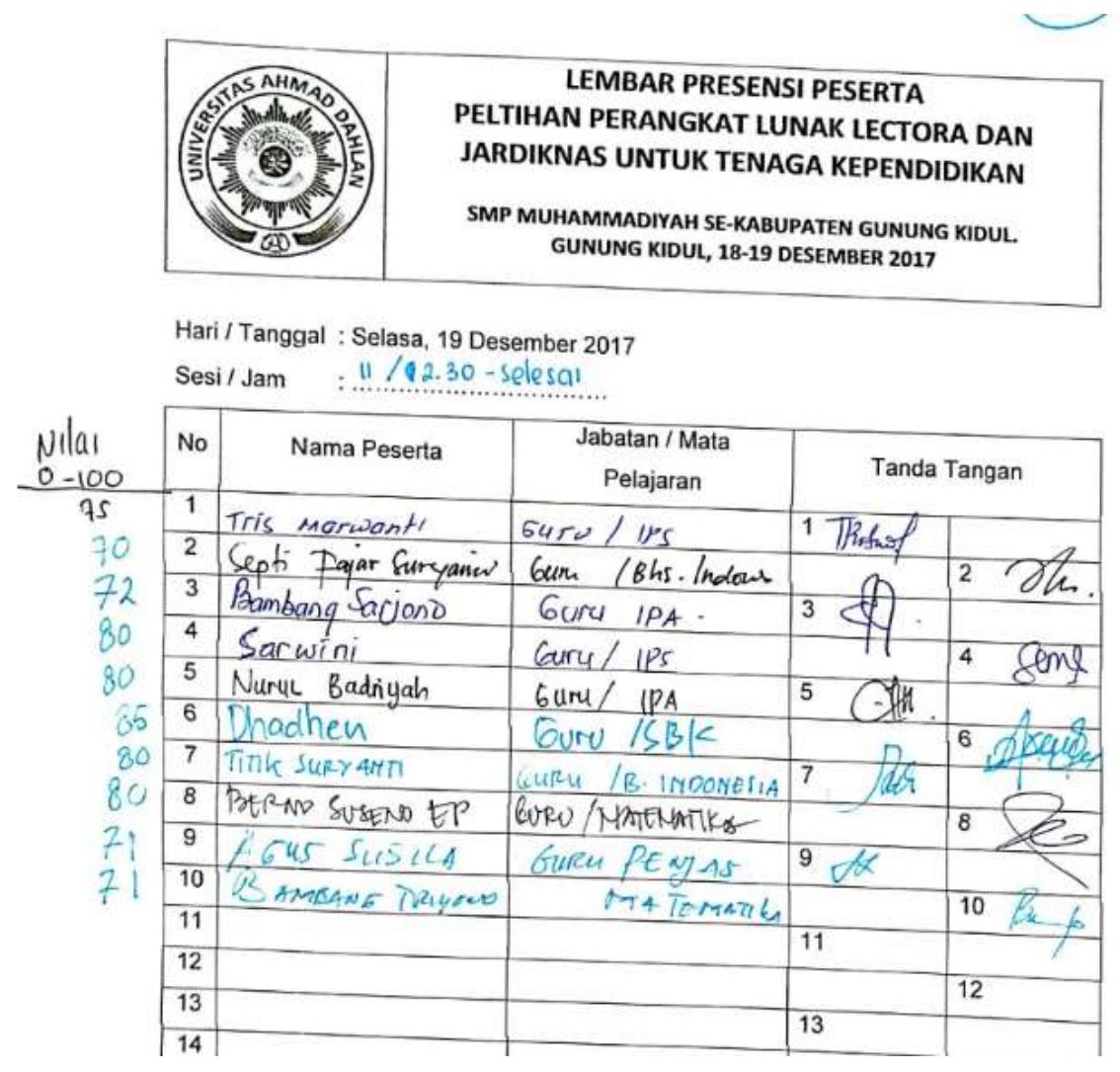

Gambar 2. Penilaian Langsung terhadap Karya Peserta

3. membuat rancangan media pembelajaran dengan fitur Design Wizard dan My Template dari Lectora yang sesuai dengan mata pelajaran yang diampu. Gambar 3 menampilkan contoh hasil rancangan yang diterapkan untuk peserta. 

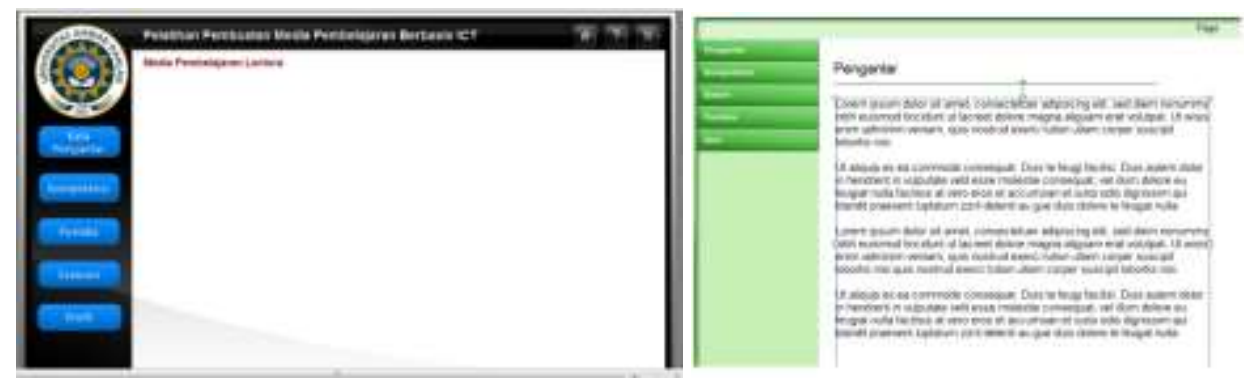

Gambar 3. Tampilan Media Lectora yang Diterapkan untuk Peserta

4. menggunakan media pembelajaran tersebut untuk keperluan pengajaran seperti membuat materi ajar, latihan soal maupun alat peraga praktikum.

5. menyebarkan kembali ilmu yang didapat kepada sesama rekan tenaga pengajar dan bagi siswa yang berminat menggunakan media belajar yang berbasis TIK.

\section{SIMPULAN}

Kesimpulan yang diperoleh dari pelatihan ini antara lain:

1. Guru-guru dan staf SMP Muhammadiyah di Kabupaten Gunungkidul yang telah mengikuti pelatihan pembuatan media pembelajaran telah dapat mengembangkan media ajar berbasis Lectora milik mereka sendiri sesuai dengan materi yang diberikan.

2. Tingkat antusiasme dan kreatifitas guru-guru dan staf SMP Muhammadiyah di Kabupaten Gunungkidul yang telah mengikuti pelatihan pembuatan media pembelajaran - dalam membuat media ajar berbasis software Lectora dinilai cukup baik, sehingga sesama rekan guru dan staf tertarik untuk mengembangkan sendiri konten ajar mereka sesuai mata pelajaran yang diampu.

\section{DAFTAR PUSTAKA}

Depdiknas. (2003). Media Pembelajaran. Jakarta: Depdiknas.

Muhson, A. (2010). PENGEMBANGAN MEDIA PEMBELAJARAN BERBASIS TEKNOLOGI INFORMASI. Jurnal Pendidikan Akuntansi Indonesia, 1-10.

Siagian, S. P. (2008). Manajemen Sumber Daya Manusia. Jakarta: Binapura Aksara.

\section{UCAPAN TERIMAKASIH}

Kegiatan pelatihan ini terlaksana dari Implementasi Program Pengabdian Masyarakat yang didanai oleh Lembaga Penelitian dan Pengabdian Masyarakat Universitas Ahmad Dahlan (LPPM UAD) dengan nomor surat tugas L2/158/J.2/XII/2017 . 